\title{
THE DEBATE ON
}

\section{THE CRUSADES}

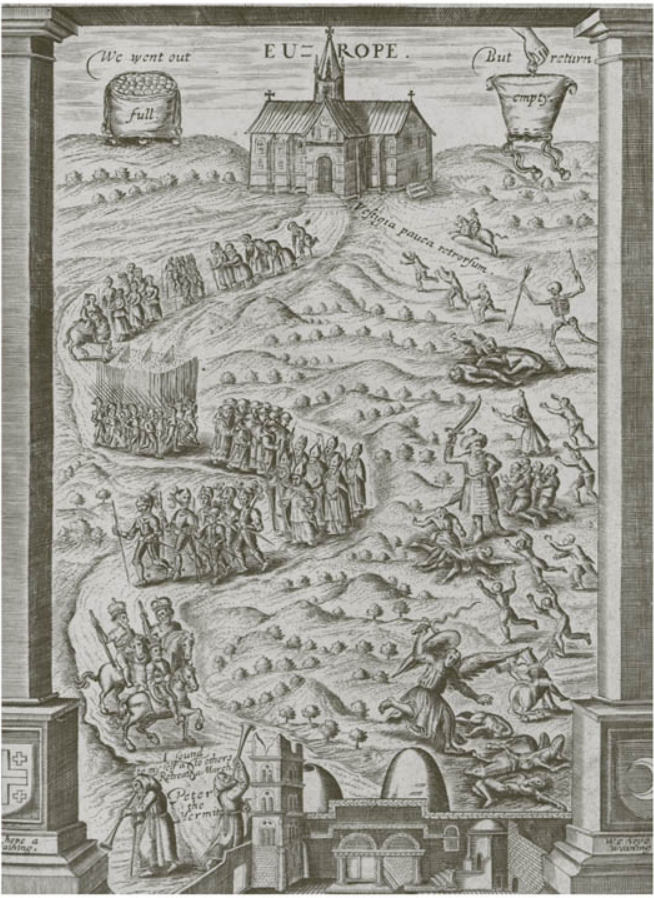

Christopher Tyerman - 9781847799005

Downtqaded from manchesterhive.com at 04/26/2023 01:28:1pPM CHRISTOPHER TYER yijafine access 
Issues in Historiography

Payer

The Debate on the Crusades

MANCHESTER

1824

Manchester University Press

Christopher Tyerman - 9781847799005 


\section{Issues in Historiography}

General editor

R. C. RICHARDSON

University of Winchester

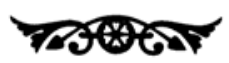

Already published

The Debate on the Norman Conquest Marjorie Chibnall

The Debate on the English Revolution

R. C. Richardson

The Debate on the French Revolution Peter Davies

The Debate on the Rise of the British Empire Anthony Webster

The Debate on the American Civil War Era H. A. Tulloch

Debates on the Holocaust

Tom Lawson

The Debate on Black Civil Rights in America Kevern Verney

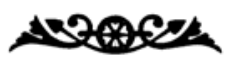


Issues in Historiography

Parerar

\title{
The Debate on the Crusades
}

\author{
CHRISTOPHER TYERMAN
}

\section{MANCHESTER UNIVERSITY PRESS}

MANCHESTER AND NEW YORK

distributed in the United States exclusively by Palgrave Macmillan 
The right of Christopher Tyerman to be identified as the author of this work has been asserted by him in accordance with the Copyright, Designs and Patents Act 1988.

Published by Manchester University Press

Oxford Road, Manchester M13 9NR, UK and Room 400, 175 Fifth Avenue, New York, NY 10010, USA

www.manchesteruniversitypress.co.uk

Distributed in the United States exclusively by

Palgrave Macmillan, 175 Fifth Avenue, New York, NY 10010, USA

Distributed in Canada exclusively by

UBC Press, University of British Columbia, 2029 West Mall,

Vancouver, BC, Canada V6T 1Z2

British Library Cataloguing-in-Publication Data

A catalogue record for this book is available from the British Library

Library of Congress Cataloging-in-Publication Data applied for

ISBN 9780719073205 hardback

ISBN 9780719073212 paperback

First published 2011

The publisher has no responsibility for the persistence or accuracy of URLs for any external or third-party internet websites referred to in this book, and does not guarantee that any content on such websites is, or will remain, accurate or appropriate.

Typeset by Action Publishing Technology Ltd, Gloucester Printed in Great Britain by TJ International 